ISSN: 2224-0616

Int. J. Agril. Res. Innov. \& Tech. 3 (1): 1-4, J une, 2013

Available online at http://www.ijarit.webs.com

\title{
ASSESSMENT OF POTABLE WATER SUPPLY SOURCES IN ILORIN METROPOLIS, KWARA STATE, NIGERIA
}

\author{
J.J. Musa ${ }^{*}$ and G.A. Fumen ${ }^{2}$ \\ Received 16 December 2012, Revised 13 May 2013, Accepted 20 June 2013, Published online 30 June 2013
}

\begin{abstract}
Water distribution system plays a vital role in preserving and providing a desirable life quality to the public. In this regards, the reliability of supply is a major component. This study was conducted using the investigative research approach method; 5000 questionnaires which were randomly distributed round the township of Ilorin and 4658 (93.16\%) were returned. Among them, 2350 respondents said that they have their own wells dugged in their respective homes, 1100 respondents had their taps running at specific periods of the week, 750 individuals said that they have boreholes available, 308 people declared that they make use of the streams and rivers running around their areas while about 150 of the remaining buy water from the water vendors so they cannot tell the exact source of the water. It was discovered that majority of the residential areas in Ilorin do not depend on the tap water supply rather they depend on dugged wells and bore holes.
\end{abstract}

Keywords: Boreholes, Dam, Flow Rate, Pumps, Supply Rate, Tanks, Water, Well

${ }^{1}$ Department of Agricultural and Bioresources Engineering, Federal University of Technology, P M B 65 Minna, Nigeria

${ }^{2}$ College of Agriculture, Ahmadu Bello University, Zaria, Nigeria

*Corresponding author's email: johnmusa125@rocketmail.com (J.J. Musa)

\section{Introduction}

Water distribution system plays a vital role in preserving and providing a desirable life quality to the public, of which the reliability of supply is a major component. Reliability analysis of a water distribution system is concerned with its ability to deliver water to individual consumers in the required quantity and under a satisfactory pressure (Al-Zahrani and Syed, 2005). Understanding the causes of water poverty is a matter of fundamental importance. The insufficient distribution of safe water is observed because of the unsustainable demographic growth, particularly in developing countries. The population pressure determines increasing national water stress, defined as a ratio between the total volume of water theoretically available in a country and the total internal population, equivalent to a value below $1000 \mathrm{~m}^{3} /$ year/per capita. The macro-regionalization of water scarcity indicates that eighty countries, involving the $40 \%$ of the total world population, are currently suffering for water stress. The logical solutions sorting out from the consideration of water stress would rather being concentrated on increasing water supply, from one side, and on policies for population control, from the other (Ahmad, 2000).

Asa dam water works situated in the northwestern part of Ilorin in the north central part of Nigeria. The city has a population of over 800,000 inhabitants. Asa dam water work is in one phase, which supplies over $300,000 \mathrm{~m}^{3}$ of water per day when the treatment plants are operational. The maximum height of the dam is about $45 \mathrm{~m}$. The raw water intake from the dam reservoir is through pipe openings at different levels in circular concrete intakes tower located within the reservoir. There are eight different levels giving the opportunity to select a particular level for raw water abstraction depending on its characteristics. Due to the height of the dam, there are three broad regions in the reservoir. The top $5 \mathrm{~m}$ in which the effects of sunlight and air are felt (called epilimnon); the bottom which is 10 meters below the surface dose not experience any form of sunlight or air (hypolimnon) and the region between them is called metalimnon (Shinstine et al., 2002). Pipelines are essential part of water distribution system, facilitating the transportation of water in varied quantities from headwork's through the treatment plants to the service reservoir and eventually to the consumers. The main trunk conveys water from source to the plant and to the service reservoir while the distribution mains from part of the distribution network and the service pipe connections made on distribution main (Lansey et al., 1989).

Untreated water also called raw water may come from groundwater or surface water sources such as lakes, rivers and streams. The raw water is usually transported to a water treatment plant 
where it is processed to produce treated water also known as portable finished water. The degree to which the raw water was processed to achieve portability depends on the characteristics of the raw water, relevant drinking water standard treatment processes and the characteristics of the distribution system (Gleick, 1996).

Before water is distributed, the treated surface water usually enters a unit clear well service, which is of three main purposes in water treatment. This provide the contact time for disinfectant such as chlorine which is added towards the end of the treatment process during which adequate contact time is required to achieve acceptable level of disaffection. Secondly, the clear well provides storage that act as a buffer between the treatment plant and the distribution system. The distribution system naturally fluctuates between periods of high and low water usage. Thus, the clear well stores excess untreated water during periods of low demand and deliver it during period of peak demand. Thirdly, the clear well can serve also as a source for back was water for cleaning plant filters which when needed is used at a high rate for a short period of time (Lawrence et al., 2002).

Transmission and distribution system of water can either be looped or branched. In the looped systems, there may be several different paths that the water can follow to get from the source to a particular consumer while in a branch system (tree system); the water has only one possible path from the source to consumers (Allen, 1998).

Planners carefully research all aspects of a water distribution system and try to determine which major capital improvement projects are necessary to ensure the quality of service for the future. The process is used to project system growth and water usage for several years to come for system and population growth. Not only can such planning be used to identify potential problem area such as future low pressure areas, water quality size, locating new transmission main pumping stations and storage facilities but can also be used to ensure that the predicted problems will not occur (Al-Zahrani and Syed, 2005).

The aim of this study is to acertain the various sources of water used for domestic services in the metropolitan city of Ilorin in the north central area of Nigeria.

\section{Methodology}

Ilorin is the state capital of Kwara located on coordinates of $8^{\circ} \quad 30^{\prime} \mathrm{N}$ and $4^{0} \quad 3^{\prime} \mathrm{E}$ (www.ilorin.org). This study was conducted using the Investigative Research Approach method, which deals with the distribution of questionnaires, personal interview and field observations. Five thousand (5000) questionnaires were randomly distributed round the township of Ilorin, the capital of Kwara State. The areas for which the questionnaires were distributed includes Adewole Estate, Harmony Estate, Government Reservation Area (GRA), the heart of Ilorin township, Saw-mail area, Kulende Housing Estate and its environs, the university permanent site, Tanke area and the Kwara State polytechnic area. The feedback from these questionnaires were analyzed and presented in graphical and chart forms.

\section{Results and Discussion}

Out of the 5000 questionnaires distributed, only 4658 (93.16\%) were returned. Table 1 shows the detailed distribution of water sources in the township area of Ilorin. Table 1 shows that 2350 respondents said that they have their own wells dugged in their respective homes, 1100 respondents said that they have taps running at specific periods of the week whereas another 750 said that they have boreholes available and 308 people said that they make use of the streams and rivers running around their areas. About 150 of the remaining buy water from water vendors so they cannot tell the exact source of the water. Figure 1 shows the percentile distribution of water sources in Ilorin

Table 1. Detailed distribution of water sources in Ilorin

\begin{tabular}{lll}
\hline Sl. No. & Water sources & Population of people using this sources \\
\hline 1 & Well & 2350 \\
2 & Tap & 1100 \\
3 & Bore Hole & 750 \\
4 & Stream/River & 308 \\
5 & Other sources & 150 \\
& Total & 4658 \\
\hline
\end{tabular}




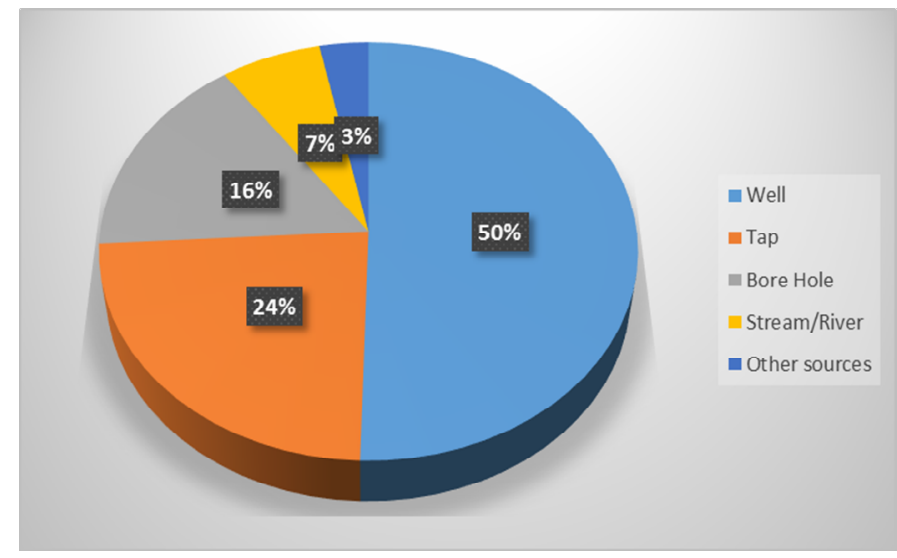

Fig. 1. Percentile distribution of water sources in Ilorin

Though most of the residents in Ilorin that have open dugged wells also have water, pipelines laid to their various houses and when asked how frequent the tap water flows they said that it runs during the rainy season only while during the dry season the taps do not run. This prompted them to get another source of water supply. This also applied to those residents with boreholes which service them during the off peak periods.

Table 2. Functionality of the various water sources in Ilorin

\begin{tabular}{llll}
\hline Sl. No. & Water Sources & Functional & Non-functional \\
\hline 1 & Well & 2350 & - \\
2 & Tap & 728 & 372 \\
3 & Bore Hole & 750 & - \\
4 & Stream/ River & 308 & - \\
5 & Other sources & 84 & 66 \\
\hline
\end{tabular}

Table 2 shows the functionality of the various sources of water throughout the year. It was discovered that only the tap water was not regular throughout the year while some of the areas where they had limited wells and boreholes complained of the slow recharge rate which was discovered was due to the rate of drawing water from the wells and boreholes was higher than the rate at which they are recharged. This implies that these various residents need to have specific times of collecting water from the wells and boreholes.

It was discovered that out of the 750 houses that had access to tap water, 180 of such houses had regular supply, which means that at any particular time of the day, water is always running from these taps. Such houses are mostly located around the government residential/reserved area of the town. One of such factor also could be the location of Agba dam, which was established to service the Government House and the principal officers working there. 230 houses visited during the course of this study indicate that the residents usually have water supply every other day. According to the respondents, the taps only start running from $8 \mathrm{am}$ in the morning to about 12 midnight of the same day. In other to have enough water to use, they install water tanks of various sizes to store water for future use. They also opinioned that the pressure of the water running from the taps was always very high which may be due to the closeness of these houses to
Agba dam. Another 198 residents stated that their taps only run once a week for 24 hours during which they store water in storage tanks for future use and when the tap does not run, they supplement their stores with the well water. They also complained about the pressure of water running from the tap, which they said was low. Most of these houses are located far away from the dam and treatment plant with a lot of branch offs from the main distribution pipeline. Because of this, a reduction of water pressure in the tap may be one of the major reasons for the poor distribution of water in the area. They also stated that only during the dry season that the rate of flow of water at once a week is usually not consistent which means that they result into going to the dam area to collect water for drinking and other domestic uses with their cars and where water vendors are available, they buy from them.

The remaining 142 residents stated that their taps run only once in two weeks which again is not regular and the pressure are usually the pressure is very low. This prompted the people in the area to get together to construct motorized boreholes with a 500,000 $\mathrm{m}^{3}$ overhead tank for easy distribution of water to the various houses. However, the Federal and State governments alongside some International donor agencies usually support these kinds of projects. Table 3 shows the rate of tap supply to the metropolitan 
city of Ilorin while Figure 2 shows the percentile rating of water supply to some residential areas of Ilorin. It was discovered that every other day water supply had the highest water supply rate of
230 houses and closely followed by the once a week supply rate of 198 houses. The lowest water supply rate was that of once in two weeks.

Table 3. Rate of tap water supply

\begin{tabular}{llll}
\hline Sl. No. & Supply Rate & No of Houses & Percentile Rating \\
\hline 1 & Regular & 180 & 24 \\
2 & Every other day & 230 & 30.67 \\
3 & Once in a week & 198 & 26.40 \\
4 & Once in 2 weeks & 142 & 18.93 \\
5 & Others & - & - \\
\hline
\end{tabular}

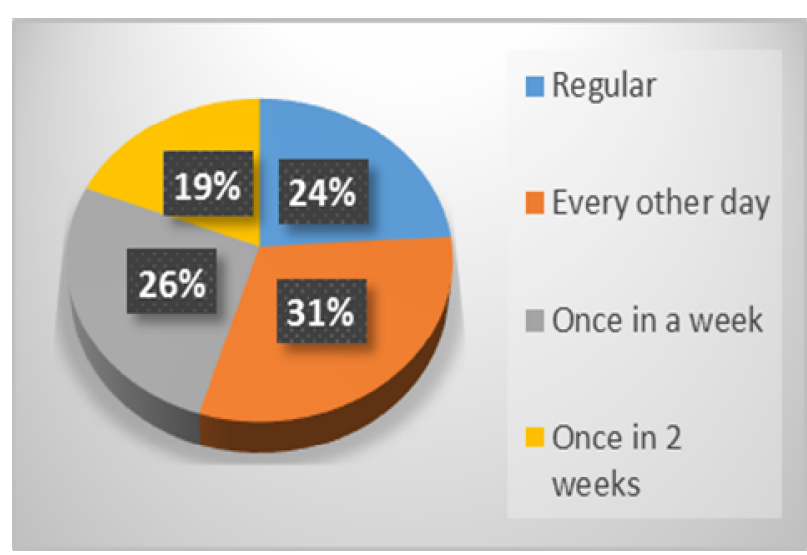

Fig. 2. The percentile rating of water supply to some residential areas of Ilorin

Most residents of Ilorin interviewed stated that the wells and boreholes were most consistent both during the dry and rainy seasons while the tap water was always regulated. The State Government through the State Ministry of Water Resources has constructed some storage tanks in some specific location of the town with no good pump stations to effectively pump water from these tanks to the public.

\section{Conclusions}

Evaluation of water distribution system in Ilorin is studied to measure the ability of meeting the consumers demand. It was discovered that majority of the residential areas in Ilorin do not depend on tap water supply rather they depend on dugged wells and bore holes. Thus, in the need to drill and dig boreholes and wells respectively resulting in almost every house. These methods of underground water extraction possess many environmental hazards such as landslides. Due to the topographical nature of Ilorin and its environment, more water storage facilities and pump stations should be provided at major areas of the town to service the residents with treated water. This will reduce the rate of drilling and digging of boreholes and wells respectively and will further enhance prompt supply of water at every other day to the residents of the town.

\section{References}

Ahmad, M. 2000. Water pricing and markets in the Near East: policy issues and options. Water Policy. 2 (3): 229-242.

Allen, J.A. 1998. Moving water to satisfy uneven global needs: 'trading' water as an alternative to engineering it. ICID Journal (International Commission on Irrigation and Drainage). 47 (2): 1-8.

Al-Zahrani, M.A. and Syed, J.L. 2005. Evaluation of municipal water distribution system reliability using minimum cut-set method. J. King Saud Univ. 18: 67-82.

Gleick, P.H. 1996. Basic water requirements for human activities: meeting basic needs. Water International. 21: 83-92.

Lansey, K.E., Duan, N. and Mays, L.W. 1989. Water distribution system design under uncertainties. ASCE J. Water Resources Planning \& Management. 115 (5): 630-644.

Lawrence, P., Meigh, J. and Sullivan, C. 2002. The water poverty index: an international comparison, Keele Economics Research Papers, $19 \mathrm{p}$.

Shinstine, D.S., Ahmed, I. and Lansey, K.E. 2002. Reliability/Availability analysis of municipal water distribution networks: case studies. ASCE J. Water Resources Planning \& Management. 128 (2): 140-151.

www.ilorin.org (Accessed on the November 16, 2008). 